\title{
An Overview of Laser Engineered Net Shaping of Ceramics
}

\section{Deposição Direta de Energia de Materiais Cerâmicos: Uma Visão Geral}

\author{
Italo Leite de Camargo ${ }^{1,2}$, João Fiore Parreira Lovo ${ }^{1}$, Rogério Erbereli ${ }^{1}$,
} Reginaldo Teixeira Coelho ${ }^{1}$, Iris Bento da Silva ${ }^{1}$, Carlos Alberto Fortulan ${ }^{1}$

\footnotetext{
${ }^{1}$ São Carlos School of Engineering - University of São Paulo - USP - Av. Trabalhador São Carlense, 400, São Carlos, SP, Brazil.

${ }^{2}$ Federal Institute of Education, Science and Technology of São Paulo - IFSP, Primeiro de Maio, 500, Itaquaquecetuba, SP, Brazil.

e-mail: italo.camargo@usp.br, joao.lovo@usp.br, rogerio.erbereli@usp.br, rtcoelho@sc.usp.br, ibs@sc.usp.br, fortulan@usp.britalo.camargo@ifsp.edu.br
}

\begin{abstract}
Additive manufacturing (AM) has provided huge versatility in geometry and materials, allowing new products and processes in several areas to be created. Laser Engineered Net Shaping (LENS) is an additive manufacturing process created in 1995 that allows building high-density metals and ceramics parts with no need for further operation. This manuscript aims to study the scientific literature about the process of Laser Engineered Net Shaping related to ceramics. After a systematic review, the articles were grouped into three categories: ceramic coating and AM of ceramics and AM of composites with ceramic reinforcement. Raw materials, substrates, applications, process parameters, and the obtained properties were analyzed and summarized for each group. Most of the additive manufacturing of ceramic parts are related to alumina, which present similar properties when compared to the traditionally manufactured ones. Recent works have the aid of an ultrasonic vibration to homogenize the in-process material, reduce cracks and improve mechanical properties. The additive manufacturing of composites with ceramic reinforcement has been used to create functionally graded composites materials with increased hardness, while the ceramic coating has been employed to manufacture biocompatible coating with increased hardness and low wear rate. Moreover, an additive manufacturing timeline including Laser Engineered Net Shaping landmarks is presented.
\end{abstract}

Keywords: Additive manufacturing, Ceramics, Direct Energy Deposition, Laser Engineered Net Shaping.

\section{RESUMO}

A manufatura aditiva (AM) tem proporcionado grande versatilidade na geometria e em materiais, permitindo que novos produtos e processos sejam criados em diversas áreas. Deposição Direta de Energia (DED) é um processo de manufatura aditiva criado em 1995 que permite a fabricação de componentes metálicos e cerâmicos com alta densidade sem a necessidade de etapas posteriores, a exemplo de sinterização ou infiltração. Este artigo objetiva o estudo do estado da arte do processo DED relacionado à cerâmica. Partindo da geração de uma linha do tempo da manufatura aditiva, que inclui os marcos relacionados à Deposição Direta de Energia, foi realizada uma revisão sistemática em que os artigos foram agrupados em 3 categorias: revestimento cerâmico, AM de cerâmica e AM de compósitos com reforços cerâmicos. Para cada categoria foram analisados, classificados e resumidos aspectos referentes às matérias primas, substratos de deposição, principais aplicações, parâmetros de processo e propriedades. A maior parte dos trabalhos referente à categoria da manufatura aditiva cerâmica está relacionada com a fabricação da alumina, sendo que propriedades já são similares às produzidas por processos convencionais de manufatura. Trabalhos recentes utilizaram a vibração ultrassônica para homogeneizar o material em processo, reduzindo trincas e melhorando as propriedades 
mecânicas. A categoria AM de compósitos com reforços cerâmicos tem sido empregada para criar materiais compósitos com gradiente funcional de elevada dureza, enquanto que a categoria de revestimentos cerâmicos tem sido majoritariamente utilizada para fabricação de revestimentos biocompatíveis com elevada dureza e baixa taxa de desgaste. De modo geral, é certo que o advento dessa tecnologia vai ocupar fatia importante da manufatura cerâmica.

Palavras-chave: Manufatura Aditiva, Cerâmica, Deposição Direta de Energia.

\section{INTRODUCTION}

In the last four decades, scientific and industrial researches have enabled considerable advances in additive manufacturing, allowing the manufacture of several products to be made of polymers, metals, ceramics, and composites with unviable or even impossible geometries by other processes [1-4]. The development of new AM techniques, materials and software have provided continuous advances in several areas $[2,5,6]$. The main benefits of AM are the ability to manufacture complex parts, fast prototypes, freedom of design, mass customization and waste minimization. On the other hand, there are still some major challenges for AM, i.e., void formation, anisotropic behavior, limitation of computer design, and layer-by-layer appearance [1].

The additive manufacturing allows fabricating complex ceramic products in small quantities, without the costs of preparing new tools each time. Such a process has been used mainly in biomedical, aerospace, automotive and chemical industries to manufacture scaffolds, filters, and lightweight structures. Challenges for AM of ceramics include dimensional inaccuracy, poor surface finish, the possible need for sintering, and the limited availability of proper feedstock, which enables the fabrication of ceramic parts with similar properties to the ones produced by conventional processing $[1,7]$.

There are two categories for AM of ceramics: the direct and indirect methods. The direct methods, in which pure ceramic powder is directly melted and solidified to create parts, include Laser Engineered Net Shaping (LENS) and Selective Laser Sintering (SLS). On the other hand, the indirect methods, in which a green body (a mixture of ceramic powder with additives as binders) is created and then sintered, include several processes (stereolithography, fused deposition, slurry-based selective laser sintering method, selective laser gelling, binder jetting and freeze-form extrusion fabrication) because of their lower dependence on high energy sources. The ceramics parts fabricated by direct AM methods can reach high values of density, purity, and mechanical properties. Moreover, it does not rely on a time-consuming binder removing step. However, the direct fabrication aided by laser is very challenging due to the intrinsic brittleness of ceramics and the high thermal gradients of the process, making it still not able to produce a wide variety of ceramics in the same way as indirect methods [8-11].

The Laser Engineered Net Shaping is a widely used term employed in the USA referring to a trademark of Sandia National Laboratories. It has several synonyms such as Direct Energy Deposition (DED), Direct Light Fabrication, Direct Laser Deposition, Direct Laser Fabrication, Laser Rapid Forming, and Laser Solid Forming $[1,12]$.

According to ISO/ASTM 52900:2015 [13], Direct Energy Deposition is defined as "an additive manufacturing process in which focused thermal energy is used to fuse materials by melting as they are being deposited". In addition, "Focused thermal energy means that an energy source (e.g. laser, electron beam, or plasma arc) is focused to melt the materials being deposited". Direct Energy Deposition differs from the SLS (another direct method) because it does not use a power bed. The raw material is melted before the deposition, which occurs layer-by-layer, similar to the Fused Deposition Modeling (FDM), but requiring a much higher energy to fuse materials, such as ceramics (Figure 1). The DED method has limitation to build complex parts, and both low accuracy and surface quality. Therefore, this method is used to manufacture lowcomplexity large parts, where the main differential it that DED can print on pre-fabricated parts, pointing out to the repair of them, such as turbines. Furthermore, the method provides great mechanical properties and it allows the fabrication of graded compositional parts $[1,14]$. 


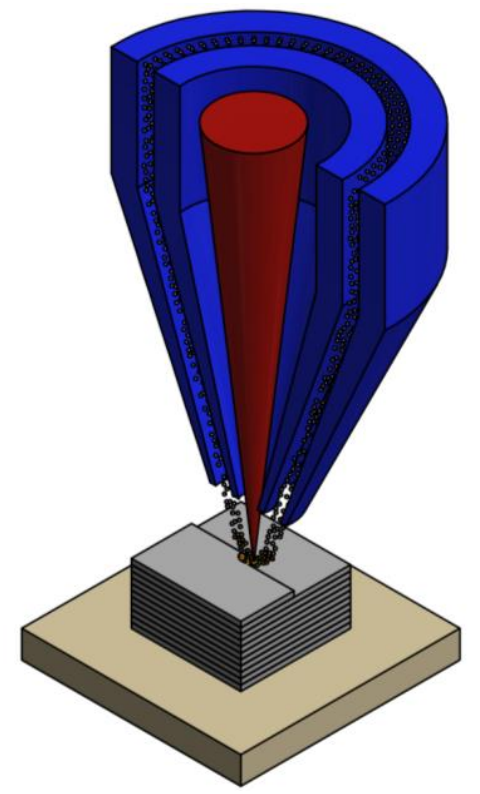

Figure 1: Schematic diagram of the Direct Energy Deposition process. The powder particles flow through the nozzle (blue) and it is melted by the focused laser (red) as it is being deposited to create a part, layer-by-layer, on the top of a substrate (beige).

The Sandia Corporation published the first articles related to Laser engineered net shaping around 1995 [15,16], while its patent was filled in 1996 [17] and it was licensed to Optomec Inc. in 1997 [18]. Even though this technique was first created to fabricate metal parts, studies indicate that some laboratories were studying the use of LENS applied to ceramics already in 1999 [19]. Figure 2 shows a timeline that includes landmarks in AM and LENS development, summarizing events portrayed in other works [2,14,25$27,15,17,19-24]$.

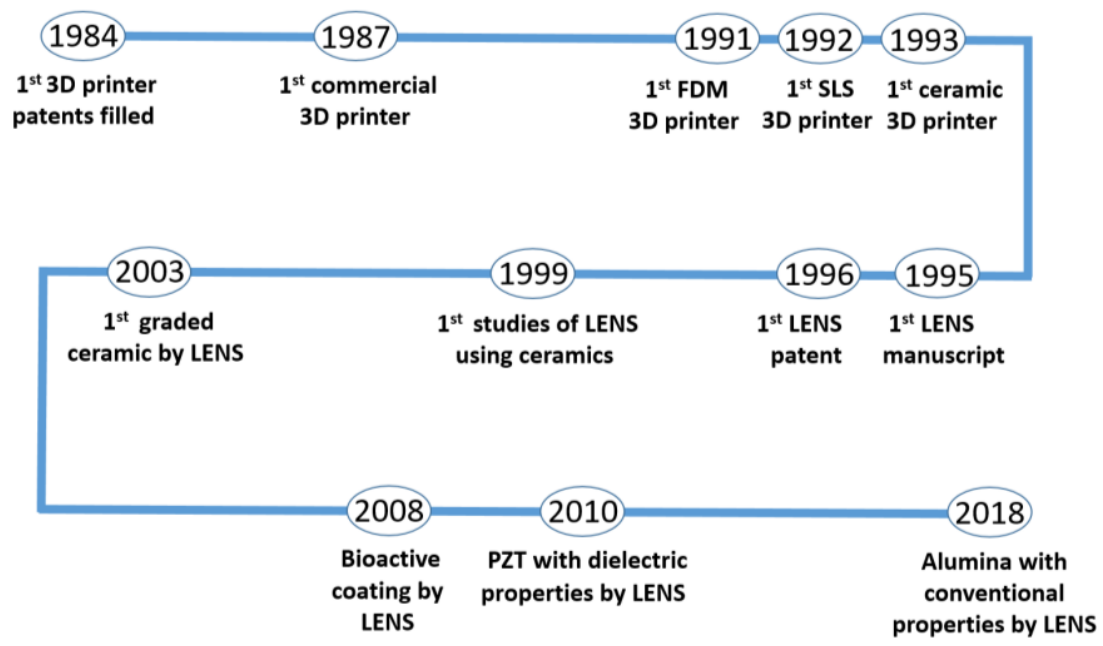

Figure 2: Additive manufacturing timeline including LENS landmarks.

\section{MATERIALS AND METHODS}

A systematic review about LENS of ceramics was performed based on SCOPUS and Web of Science databases. The terms included on the search were "Laser Engineered Net Shaping" and "Ceramics", excluding articles when LENS was not the main topic. Manuscripts published in English until August 15, 2018 were analyzed and divided into three major groups: coating of ceramics, AM of ceramics and of composites with ceramic reinforcement. For each category, we examined the literature on applications, raw 
materials specifications, process parameters, and obtained properties.

\section{RESULTS}

During our investigation, the number of articles found in Web of Science and Scopus was 37 and 48, respectively. By eliminating the duplicated papers, the manuscripts not written in English and the ones in which LENS were not the main topic, 31 articles were selected for the analysis. Figure 3 shows the number of manuscripts published over the years, where more than $50 \%$ of the papers have been published in the last 3 years. It is clear that the number of manuscripts published has increased mainly in the newest category: AM of ceramics.

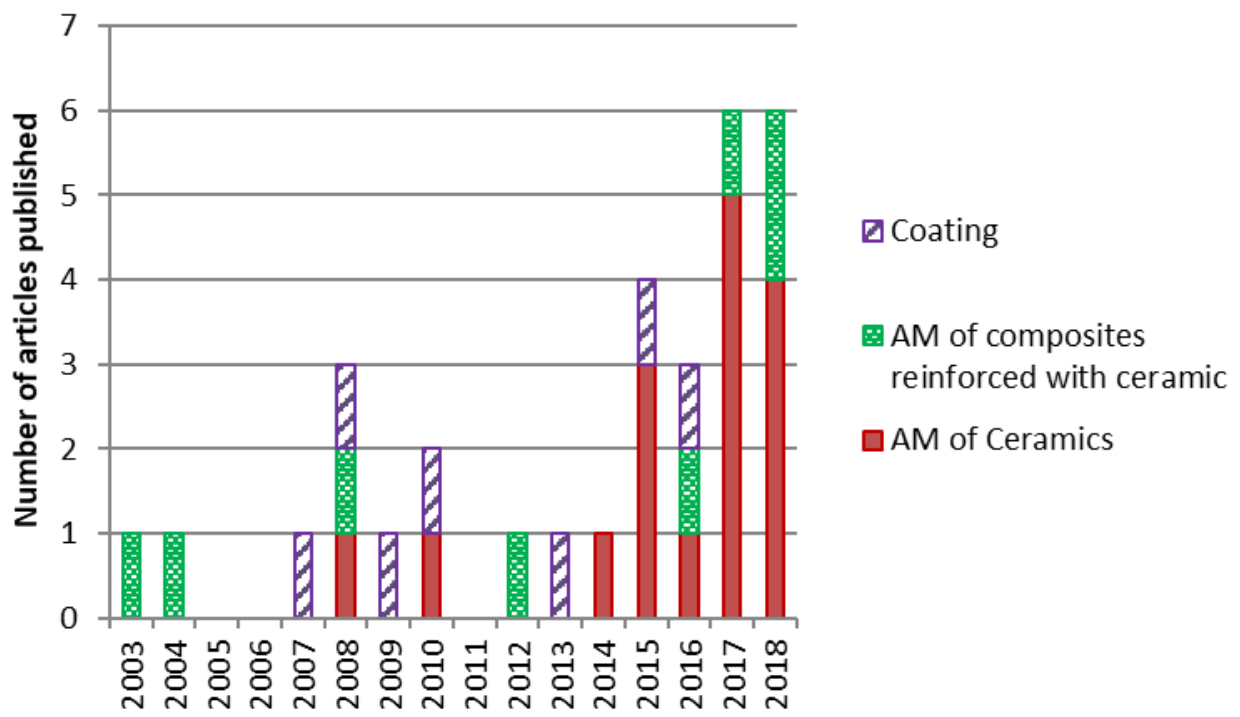

Figure 3: Articles related to LENS of ceramics published between 2003 and 2018 regarding coating, AM of composites reinforced with ceramic and AM of ceramics. A growth in the number of published articles in such topic is evident.

\subsection{Additive Manufacturing of Ceramics}

\subsubsection{Raw materials and substrate:}

Alumina was used as the raw material in 15 of the 16 employed articles related to AM of ceramics. It was employed to deposit $\mathrm{Al}_{2} \mathrm{O}_{3}$ [8-10, 27-30], $\mathrm{Al}_{2} \mathrm{O}_{3} / \mathrm{ZrO}_{2}$ [29-37], $\mathrm{Al}_{2} \mathrm{O}_{3} / \mathrm{YAG}$ (yttrium aluminum garnet) [30,38] and $\mathrm{Al}_{2} \mathrm{O}_{3} / \mathrm{SiC}$ [29]. These manuscripts utilized powders with a particle size of about $40-90 \mu \mathrm{m}$. The only exception is a recent paper [31] in which the fused yttria-stabilized $\mathrm{ZrO}_{2}$ had a particle size of about 1-5 $\mu \mathrm{m}$. The authors state that different particle size ranges between $\mathrm{Al}_{2} \mathrm{O}_{3}$ and $\mathrm{ZrO}_{2}$ powders could ensure an interactive mixture between them. In addition, several recent articles have used spherical powders [3235,38]. It was shown by Durejko et al. [39] that spherical powders have a smooth and problem-free feeding process during LENS fabrication. Moreover, some studies [8,27-30,37,38] indicate that the powder should be dried to eliminate moisture. According to Niu et al. [38], such a process increases the flowability of the powder. Figure 4 presents a confocal image of a spherical alumina powder, similar to the raw material utilized in the already mentioned articles. 


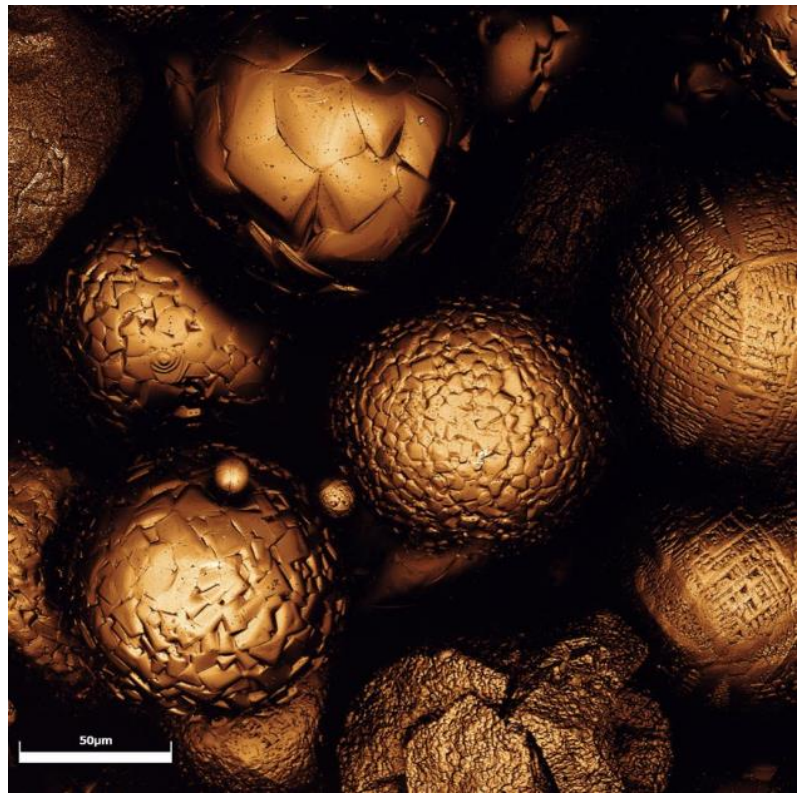

Figure 4: Confocal image of spherical Alumina powder.

The most used substrates in these processes were alumina [8-10,27,28,37] and the titanium alloy Ti$6 \mathrm{Al}-4 \mathrm{~V}$ [29,30,32,34,38]. The thickness of alumina substrate varied between 3 and $50 \mathrm{~mm}$, while substrates of Ti-6Al-4V with a thickness between 6 and $9 \mathrm{~mm}$ were employed. The use of Ti-6Al-4V is due to its good compatibility and high laser absorptivity [29].

Lead zirconate titanate (PZT) was the raw material adopted by the only article that did not use alumina [26], where the particle size was approximately $1 \mu \mathrm{m}$. A heat treatment was made to create agglomerates between 50 and $150 \mu \mathrm{m}$ and to remove moisture, suiting the powder for the LENS process in a 316L stainless steel substrate (thickness of $3 \mathrm{~mm}$ ).

\subsubsection{Process parameters:}

All the papers utilized continuous wave of Nd:YAG laser in the process. The laser power adopted in the articles related to AM of ceramics varied between 150 and $530 \mathrm{~W}$. The scan speed varied between 100 and $1500 \mathrm{~mm} / \mathrm{min}$, but most manuscripts used a speed between 300 and $400 \mathrm{~mm} / \mathrm{min}$ [8,27,30,32,33,35-38]. The powder feed rate varied from 0.2 to $3.0 \mathrm{~g} / \mathrm{min}$, but most papers employed a power feed rate between 1.6 and $2.4 \mathrm{~g} / \mathrm{min}$ [27,31-38]. Some articles did not provide the $\mathrm{z}$-increment, which is equivalent to the layer thickness. All the manuscripts that specified this parameter [10,27,28,30-33,35,37,38] adopted an increment range between 0.18 and $0.51 \mathrm{~mm}$.

The use of ultrasonic vibration to assist LENS is also reported in a few papers [31-33,35]. According to $\mathrm{Hu}$ et al. [31], this emerging technique reduces the initiation and propagation of cracks and improves mechanical properties such as microhardness or wear resistance, for example. An ultrasonic vibration unit provides vertical ultrasonic vibration, which is transmitted to the surface of the substrate homogenizing the material dispersion. The ultrasonic power used was up to $160 \mathrm{~W}[32,33,35]$ and should increase as the parts became higher, in order to ensure an equivalent effect. The ultrasonic frequency and amplitude adopted by Hu et al. [31] was $41 \mathrm{kHz}$ and $5 \mu \mathrm{m}$, respectively.

\subsubsection{Properties and samples:}

Recent articles related to LENS of alumina have presented samples with properties on the same level as the conventional fabricated ones. Niu et al. [27] produced samples with a relative density of $99.5 \%$, the average flexural strength of $210 \mathrm{MPa}$, and average compressive strength of $395 \mathrm{MPa}$. However, the parts had nonuniform defects size and, as a consequence, great dispersion of these properties. Li et al. [9] produced by LENS samples with microhardness as high as $2400 \mathrm{HV}$ overcoming the one provided by other processes due to its unique melting solidification process. A major problem in the samples is the presence of cracks and, in order to reduce it, dopings such as yttria, zirconia, and silicon carbide were used. 
On one hand, Silicon Carbide ( $\mathrm{SiC}$ ) suppresses cracks by dispersion strengthening mechanism, since it has higher binding strength and melting point, and so its dispersion in the alumina matrix demands more propagation energy. On the other hand, yttria and zirconia suppress cracks by grain refinement strengthening [29,30]. Niu et al. [38] produced Alumina/YAG eutectic ceramic with a relative density of $98.6 \%$ and microhardness and fracture similar to those achieved by traditional methods.

Eutectic Zirconia/Alumina was produced by several manuscripts, where crack-free single-bead wall parts were made [29] and low porosity (0.45\%) reached [33]. Finer microstructures provided higher properties than traditional Eutectic Zirconia/Alumina. For instance, eutectic spacing about $60-70 \mathrm{~nm}$ provided fracture toughness of 7.67 MPa.m ${ }^{1 / 2}[32,35]$

Moreover, PZT ceramic with reasonable dielectric properties was manufactured on a metallic substrate using LENS pointing out the direct fabrication of embedded sensors, which is not possible by any other AM or conventional process. There was a loss of the dielectric properties of the PZT during the LENS process that is explained by the formation of a different phase during the process. Such a loss in the dielectric properties can be mitigated by increasing the quantity of oxygen in the glove box and the amount of $\mathrm{PbO}$ in the raw material. However, rapid cooling is intrinsic to the process and it should lead to some loss of the dielectric properties [26].

\subsection{Coating of Ceramics}

\subsubsection{Raw materials, substrate, and application:}

Bandyopadhyay et al. [40] created compositionally graded alumina coatings on a $3.16 \mathrm{~mm}$ thick 316 stainless steel substrate. The pure alumina powder particle size was between 44-74 $\mu \mathrm{m}$ and the bond coat utilized was $\mathrm{Ni}-20 \mathrm{wt} \% \mathrm{Cr}$ powder (45-106 $\mu \mathrm{m})$. Zheng et al. [41] deposited IN625 (particle size from 45 to $125 \mu \mathrm{m}) \mathrm{Ni}$ based metal matrix composites with TiC ceramics (particles with size up to $45 \mu \mathrm{m}$ ) on a 316 stainless steel substrate.

Balla et al. [42] coated compositionally graded $\mathrm{TiO}_{2}$ ceramic on a titanium substrate in order to study possible improvements in load-bearing implants. In this case, it was used pure titanium (particle size between 50 and $150 \mu \mathrm{m}$ ) and $\mathrm{TiO}_{2}$ powder (from 45 to $106 \mu \mathrm{m}$ ). Roy et al. [25] produced a tricalcium phosphate (particle size from 45 to $150 \mu \mathrm{m}$ ) coating on a $0.89 \mathrm{~mm}$ thick titanium substrate, also aiming the application in load-bearing implants. Don et al. [43] reviewed the application of LENS in the fabrication of biomedical implants. Also, he presented LENS as a potential technique for manufacturing unitized mono-block prosthesis (one part with different compositions and functionality) with ceramic reinforced metal matrix composites coatings with graded composition and functional gradation porosity. Some related works took place after this review and are presented afterward.

Ti-Si-N was employed to create a coating with high hardness and wear resistance on the pure titanium substrate. Pure Ti powder (size range from 44 to $149 \mu \mathrm{m}$ ) and silicon powder (particle size up to $44 \mu \mathrm{m}$ ) were mixed in a dry ball mill. This research also has potential on biomedical implants [44].

$\mathrm{SiC}$ powder (particle size from 50 to $150 \mu \mathrm{m}$ ) was used to create a reinforced titanium matrix composite (TMC) on a titanium surface. Titanium matrix composite coatings enhanced corrosion resistance and increased the wear resistance of titanium by about 100 times. Moreover, such coating is not toxic and it has reduced metal ion release, being suitable for implants [45].

Gualtieri et al. [46] deposited a compositionally gradient coating of vanadium carbide (VC) and 304 stainless steel on a stainless steel substrate. It can be employed to improve the functionality of the surface or even to produce net shape repair parts.

\subsubsection{Process parameters:}

The laser power utilized in the manuscripts related to the coating of ceramics varied between 280 and $650 \mathrm{~W}$. Also, the scan speed varied between 560 and $2400 \mathrm{~mm} / \mathrm{min}$. Yet, the powder feed rate varied from 9.0 to 27.6 $\mathrm{g} / \mathrm{min}$

\subsubsection{Properties and samples:}

Bandyopadhyay et al. [40] created crack-free alumina coatings with hardness more than $50 \%$ higher than plasma sprayed alumina coatings ones and it also had better bonding strength between the coating and the substrate. 
The IN625 metal matrix composites components with Ni-coated particles TiC were fabricated using LENS [41]. On one hand, the samples with $20 \mathrm{wt} \%$ of TiC/Ni presented a yield strength of $690 \mathrm{MPa}$ (almost $40 \%$ higher than conventional IN625), but in the other hand, it has a relatively low ductility (3.5\%).

Pointing out to the application of LENS in biomedical applications, biocompatible coatings were covered in a few articles. Non-toxic coatings with increased wettability, cell-material interactions, lubrication ability, and hardness were manufactured [42]. Tricalcium phosphate coating was produced with a hardness greater than $1000 \mathrm{HV}$ (more than 5x higher than the substrate hardness) [25].

The $\mathrm{SiC}$ reinforced titanium matrix composite coatings produced by LENS are biocompatible and more bioinert than titanium substrate. Furthermore, the coating has a wear rate 100 times lower than the employed substrate [45]. In addition, other studies indicate a wear reduction, such as a vanadium carbide coating which decreased the wear rate of stainless steel by $95 \%$ [46].

\subsection{Additive manufacturing of composites with a ceramic reinforcement}

\subsubsection{Raw materials and substrate:}

Liu and Dupont [14] fabricated Ti/TiC functionally graded composites on Ti-6Al-4V substrates (3.175 mm thick) by continuously varying the proportions of the components. The powders (particle size between 45 and $150 \mu \mathrm{m})$ were placed in separate feeders and mixed in situ while feeding from the powder feeders to the nozzles. On the other hand, the same authors deposited $\mathrm{Ti}-48 \mathrm{Al}-2 \mathrm{Cr}-2 \mathrm{Nb}$ and $\mathrm{TiC}(20 \mathrm{vol} \%)$ powder (particle diameters also between 45 and $150 \mu \mathrm{m}$ ) on the same substrate [47]. In this case, the powders could pre mixed and placed in a single powder feeder since the proportion in this case was not variable.

Most subsequent investigations used ceramic particles to reinforce TiAl-based alloys. For instance, Zheng et al. [49] and Ochonogor et al. [50] used composites based on Ti-6Al-4V (spherical powder with particle size from 45 to $106 \mu \mathrm{m}$ ) and substrates of the same material (around $6.5 \mathrm{~mm}$ ). On one hand, 10 and $20 \mathrm{wt} \% \mathrm{Ni}$-coated TiC $(10-80 \mu \mathrm{m})$ were pre-mixed with the metal matrix by a v-blender [49]. On the other hand, irregularly shaped TiC (45-125 $\mu \mathrm{m})$ and Zirconium (32-125 $\mu \mathrm{m})$ were used for matrix reinforcement $(10,20$ and $30 \mathrm{vol} \%)$ with the use of independent feeders and mixing occurring during the deposition process [50].

Moreover, two works used alumina-reinforced metal alloys. Zhang e Bandyopadhyay [48] fabricated compositionally graded structures from pure Ti6Al4V to pure $\mathrm{Al}_{2} \mathrm{O}_{3}$. This change in composition during manufacturing again required independent feeders (in situ mixing). The powders varied from 44 to $74 \mu \mathrm{m}$ and a $3 \mathrm{~mm}$ thick Ti-6Al-4V substrate was used. Lastly, Łazińska et al. [51] pre-mixed 2 vol\% of nanometric alumina powder (with particle size of $35 \mathrm{~nm}$ ) and FeAl alloy powder (particle size from 44 to $150 \mu \mathrm{m}$ ) in a planetary mill to obtain an uniform distribution of the ceramic on the surface of the base powder particles. In this case, it was used an $11 \mathrm{~mm}$ thick sand-blasted Armco iron substrate.

\subsubsection{Process parameters:}

The laser power used in the articles related to AM of composites with ceramic reinforcement varied between 170 and $750 \mathrm{~W}$, while the scan speed varied from 234 to $1014 \mathrm{~mm} / \mathrm{min}$. The powder feed rate of the works that used Ti-6Al-4V as matrix [48-50] varied from 10 to $33 \mathrm{~g} / \mathrm{min}$, contrasting with works that used Ti [14] and $\mathrm{Ti}-48 \mathrm{Al}-2 \mathrm{Cr}-2 \mathrm{Nb}$ [47] whose rate varied from 1 to $3.5 \mathrm{~g} / \mathrm{min}$. The lowest power feed rate, $0.16 \mathrm{~g} / \mathrm{min}$, was used in the deposition of $\mathrm{FeAl}$ alloy reinforced by nanometric alumina [51]. Thus a large variation in the parameters used is seen. The optimization of one of the parameters depends on not only in the others parameters but also in several factors, such as physical properties of deposited material, the ambient conditions, etc [8]

It is interesting to note that compositionally graded structures may require adjusted processing parameters. Zhang e Bandyopadhyay [48] used higher laser power and lower scan speed for pure metal layers than for composites or pure ceramic layers.

\subsubsection{Properties and samples:}

A functionally graded composite material was fabricated varying the composition from pure Ti ( 0 vol\% of $\mathrm{TiC}$ ) to $95 \mathrm{vol} \%$ of $\mathrm{TiC}$ ( $5 \mathrm{vol} \%$ of $\mathrm{Ti}$ ). The hardness reached $2300 \mathrm{HV}$ with a high content of ceramics, which is more than $11 \mathrm{x}$ the hardness of pure Ti [14]. Also, Liu et al. [47] found that pre-heating the substrate is an effective method for eliminating cracks during the LENS process. Crack-free deposits were obtained 
with a substrate pre-heated between 450 and $500^{\circ} \mathrm{C}$, laser power of $300 \mathrm{~W}$ and scan speed less than 762 $\mathrm{mm} / \mathrm{min}$.

Zhang et al. [48] fabricated $\mathrm{Ti}-\mathrm{Al}_{2} \mathrm{O}_{3}$ compositionally graded structures and a Ti-6 $\mathrm{Al}-4 \mathrm{~V} / \mathrm{Al}_{2} \mathrm{O}_{3}$ section overcame $1000 \mathrm{HV}$ while a pure $\mathrm{Al}_{2} \mathrm{O}_{3}$ section reached $2365 \mathrm{HV}$. In another research, [49] and Ti-6Al$4 \mathrm{~V}$ with $30 \mathrm{vol} \%$ of TiC presented $550 \mathrm{HV}$. Yet, nanometric alumina reduced the porosity (from $5 \%$ to $1 \%$ ) and the oxidation in $\mathrm{FeAl}$ alloys [51].

\section{CONCLUSIONS}

The LENS is an AM process that can build dense ceramic parts with no need for further operation and this method was initially created to manufacture metal parts in 1995. However, in 1999 some laboratories already studied this method applied to ceramics. A systematic review about LENS of ceramics was made based on articles written in English published until August 2018 available in SCOPUS and Web of Science databases, where an analysis was made and divided into three major groups: AM of ceramics, AM of composites with ceramic reinforcement and coating of ceramics. The increase in the number of publications is evident, mainly in the most recent area defined as additive manufacturing of ceramics. However, some potentials of LENS applied to ceramic remain unexplored, such as the repair of pre-fabricated parts, which is a technique already well-known for metals. Considering AM of ceramics, all articles, with the exception of one, used alumina (pure or doped). Such usage can be explained not only by the great mechanical properties but mainly because there is a shortage of other ceramic raw materials suitable to the process (spherical powder with proper particle size distribution). Recent works provided samples with similar properties to the ones reached by conventional manufacture processes. Furthermore, one article used PZT obtaining reasonable dielectric properties and pointing out the direct fabrication of embedded sensors.

Considering AM of composites with ceramic reinforcement, it allows the production of compositionally graded structures with increased hardness and compressive yield strength and reduced oxidation. Most coatings of ceramics are related to biocompatible implants aiming at better properties, such as increased hardness and lower wear rates. To sum up, a review was made in order to contextualize the LENS of ceramics in the history of AM and to provide information for future research about it.

Therefore, the process showed to be able to coat and produce by additive manufacturing ceramic and composites with ceramic reinforcement. It is also capable of producing functionally graded composites. For this purpose, independent feeders are needed and the process may require adjusted processing parameters.

Although there are several works that intend to optimize the process parameters, they point to quite different results, depending on the case analyzed. Parameters such as powder feed rate varied over 200 times in works related to AM of composites. Such heterogeneous works did not allow them to be gathered in a meta-analysis.

\section{ACKNOWLEDGMENTS}

This study was financed in part by the coordenação de aperfeiçoamento de pessoal de nível superior - Brasil (Capes) - finance code 001.

\section{BIBLIOGRAPHY}

[1] NGO T.D., KASHANI A., IMBALZANO G., et al., "Additive manufacturing (3D printing): A review of materials, methods, applications and challenges", Composites Part B., v.143, pp. 172-196, Jun. 2018.

[2] GIBSON I., ROSEN D., STUCKER B., Additive Manufacturing Technologies: 3D Printing, Rapid Prototyping, and Direct Digital Manufacturing, 2 ed., New York, Springer, 2015.

[3] CHIU S.H., GAN S.Y., TSENG Y.C., et al., "Multi-objective optimization of process parameters in an area-forming rapid prototyping system using the Taguchi method and a grey relational analysis", Proc IMechE, Part B: J Engineering Manufacture, v.231, n.12, pp. 2211-2222, Oct. 2017.

[4] KIM H., LIN Y., TESENG T.L.B., "A review on quality control in additive manufacturing”, Rapid Prototyping Journal, v.24, n.3, pp. 645-669, Apr. 2018.

[5] KOLESKY D.B., TRUBY R.L., GLADMAN A.S., et al., "3D bioprinting of vascularized, heterogeneous cell-laden tissue constructs”, Advanced Materials, v.26, n.19, pp. 3124-3130, May 2014.

[6] BASZYNSKI, M., RAMOTOWSKI, E., OSTASZEWSKI, D., et al., "Evaluation of new technologies and materials for printed circuit boards with improved heat dissipation properties", Circuit World, v.42, n.1, pp. 32-36, Feb. 2016. 
[7] ZOCCA, A., COLOMBO, P., GOMES, C.M., et al., "Additive Manufacturing of Ceramics: Issues, Potentialities, and Opportunities”, Journal American Ceramic Society, v.98, n.7, pp. 1983-2001, Jul. 2015. [8] NIU F., WU D., ZHOU S., et al., "Power prediction for laser engineered net shaping of $\mathrm{Al}_{2} \mathrm{O}_{3}$ ceramic parts", Journal of the European Ceramic Society, v.34, n.15, pp. 3811-3817, Dec. 2014.

[9] LI Y., HU Y., CONG W., et al., "Additive manufacturing of alumina using laser engineered net shaping: Effects of deposition variables", Ceramics International, v.43, n.10, pp. 7768-7775, Jul. 2017.

[10] BALLA V.K., BOSE S., BANDYOPADHYAY A., "Processing of bulk alumina ceramics using laser engineered net shaping", International Journal of Applied Ceramic Technology, v.5, n.3, pp. 234-242, May 2008.

[11] DECKERS J., VLEUGELS J., KRUTH J.P., “Additive manufacturing of ceramics: A review”, Journal of Ceramic Science and Technology, v.5, n.4, pp. 245-260, Dec. 2014.

[12] GU D. D., MEINERS W., WISSENBACH K., et al., "Laser additive manufacturing of metallic components: materials, processes and mechanisms", International Materials Review, v.57, n.3, pp. 133-164, Nov. 2013.

[13] INTERNATIONAL ORGANIZATION FOR STANDARDIZATION/AMERICAN SOCIETY FOR TESTING AND MATERIALS. ISO/ASTM 52900 - Additive manufacturing - General principles Terminology, 2015.

[14] LIU W, DUPONT J.N., "Fabrication of functionally graded TiC/Ti composites by laser engineered net shaping”, Scripta Materialia, v.48, n.9, pp. 1337-1342, May 2003.

[15] KEICHER D.M., JELLISON J.L., SCHANWALD L.P., et al., "Towards a Reliable Laser Spray Powder Deposition System Through Process Characterization", In: 27 International Technical Conference of the Society for the Advancement of Material and Process Engineering (SAMPE): diversity into the next century, Albuquerque, New Mexico, United States, 1995.

[16] GRIFFITH M.L., KEICHER D.M., ATWOOD C.L., et al., "Free Form Fabrication of Metallic Components Using Laser Engineered Net Shaping (LENS)", In: 7th Solid freeform fabrication symposium. pp. 125-132, Austin, Texas, United States, 1996.

[17] UNITED STATES PATENT, F.P. JEANTETTE., Method and system for producing complex-shape objects, US Patent: 6046426, Apr 2000.

[18] MUDGE, R.P., WALD, N.R., "Laser engineered net shaping advances additive manufacturing and repair", Welding Journal-New York, v.86, pp.44-48, Jan 2007.

[19] SEARS J.W., "Direct Laser Powder Deposition - State of the Art", in ASTM/TMS Materials Week, pp.213-226, Cincinnati, OH, USA, Nov 1999.

[20] BÁRTOLO P.J., GIBSON I., "History of Stereolithographic Processes", In: Bártolo P. (eds) Stereolithography, chapter 2, Boston, USA, Springer, 2011.

[21] UNITED STATES PATENT, C.W. Hull, Apparatus for production of three-dimensional objects by stereolithography - US Patent: 4575330, Mar 1986.

[22] AMERICAN SOCIETY FOR TESTING AND MATERIALS, ASME Historic Mechanical Engineering Landmark: Stereolithography - The first 3D printing technology, May 2016.

[23] PRINZ F.B., ATWOOD C.L., AUBIN R.F., et al., Rapid Prototyping in Europe and Japan, v.1, Baltimore, USA, Rapid Prototyping Association of the Society of Manufacturing Engineers, 1997.

[24] WOHLERS T., GORNET T., "History of Additive Manufacturing", In: Wohler Report 2017 - 3D Printing and Additive Manufacturing State of the Industry - Annual Worldwide Progress Report, Wholers Associate Inc., 2014.

[25] ROY, M., KRISHNA, V. B., BANDYOPADHY,AY, et al., "Laser processing of bioactive tricalcium phosphate coating on titanium for load-bearing implants", Acta Biomaterialia, v.4, n.2, pp.324-333, Mar 2008.

[26] BERNARD S. A., BALLA V. K., BOSE S., et al., "Direct laser processing of bulk lead zirconate titanate ceramics", Materials Science Engineering B. v.172, n.1, pp. 85-88, Aug 2010.

[27] NIU, F., WU, D., LU, F., et al., "Microstructure and macro properties of $\mathrm{Al} 2 \mathrm{O} 3$ ceramics prepared by laser engineered net shaping", Ceramics International, v.44, n.12, pp.14303-14310, Aug 2018.

[28] NIU, F.Y., WU, D.J., YAN, S., et al., "Process Optimization for Suppressing Cracks in Laser Engineered Net Shaping of A12O3 Ceramics", Jom - The Journal of the minerals, metals \& materials society 
(TMS), v.69, n3, pp.557-562, Mar 2017.

[29] NIU, F., WU, D., MA, G., et al., “Additive manufacturing of ceramic structures by laser engineered net shaping”, Chinese Journal of Mechanical Engineering, English Ed. v.28, n.6, pp.1117-1122, Aug 2015.

[30] NIU, F., WU, D., MA, G, et al., "Effect of second-phase doping on laser deposited Al2O3 ceramics", Rapid Prototyping Journal, v.21, n.2, pp. 201-206, Mar 2015.

[31] HU, Y., NING, F., CONG, W., et al., "Ultrasonic vibration-assisted laser engineering net shaping of $\mathrm{ZrO} 2-\mathrm{Al} 2 \mathrm{O} 3$ bulk parts: Effects on crack suppression, microstructure, and mechanical properties", Ceramics International, v.44, n.3, pp.2752-2760, Feb 2018.

[32] YAN, S., WU, D, MA, G, et al., "Nano-sized Al2O3-ZrO2 eutectic ceramic structures prepared by ultrasonic-assisted laser engineered net shaping", Materials Letters, v.212, pp.8-11, Feb 2018.

[33] YAN, S., WU, D., NIU, F., et al., "Effect of ultrasonic power on forming quality of nano-sized Al2O3$\mathrm{ZrO} 2$ eutectic ceramic via laser engineered net shaping (LENS)", Ceramics International, v.44, n.1, pp.1120-1126, Jan 2018.

[34] YAN, S., WU, D., MA, G., et al., "Formation mechanism and process optimization of nano Al2O3$\mathrm{ZrO} 2$ eutectic ceramic via laser engineered net shaping (LENS)", Ceramics International, v.43, n.17, pp.14742-14747, Dec 2017.

[35] YAN, S., WU, D., NIU, F., et al., "Al2O3-ZrO2 eutectic ceramic via ultrasonic-assisted laser engineered net shaping”, Ceramics International, v.43, n.17, pp.15905-15910, Dec 2017.

[36] MA, G., YAN, S., NIU, F., et al., "Microstructure and mechanical properties of solid AL2O3ZRO2(Y2O3) eutectics prepared by laser engineered net shaping", Journal of Laser Application. v.29, n.2, pp. 022305-1-022305-6, May 2017.

[37] NIU, F., WU, D., MA, G, et al., "Nanosized microstructure of Al2O3-ZrO2(Y2O3) eutectics fabricated by laser engineered net shaping”, Scripta Materialia, v.95, n1, pp.39-41, Jan 2015.

[38] NIU, F., WU, D., MA, G., et al., "Rapid Fabrication of Eutectic Ceramic Structures by Laser Engineered Net Shaping”, In: 18th CIRP Conference on Electro Physical and Chemical Machining, Procedia CIRP, v.42 pp.91-95, 2016.

[39] DUREJKO, T., ANISZEWSKA, J., ZIETALA, M., et al., "The application of globular water-atomized iron powders for additive manufacturing by a LENS technique", Materials - Basel, v.11, n.5, pp.1-12, May 2018.

[40] BANDYOPADHYAY, P.P., BALLAV, K., BOSE, S., et al., "Compositionally graded aluminum oxide coatings on stainless steel using laser processing”, Journal of American Ceramic Society. v.90, n.7, pp.19891991, Jul 2007.

[41] ZHENG, B., TOPPING, T., SMUGERESKY, J. E., et al., "The influence of Ni-coated TiC on laserdeposited IN625 metal matrix composites", Metallurgical and Materials Transactions A, v.41, n.3, pp.568573, Mar 2010.

[42] BALLA, V.K., DEVASCONCELLOS, P.D., XUE, W., et al., "Fabrication of compositionally and structurally graded Ti-TiO2 structures using laser engineered net shaping (LENS)", Acta Biomaterialia, v.5, n.5, pp.1831-1837, Jun 2009.

[43] DAS, M., BALLA, V.K., KUMAR, T.S.S., et al., "Fabrication of Biomedical Implants using Laser Engineered Net Shaping (LENSTM)", Transactions of the Indian Ceramic Society, v.72, n.3, pp.169-174, Oct 2013.

[44] ZHANG, Y., SAHASRABUDHE, H., BANDYOPADHYAY, A., “Additive manufacturing of Ti-Si-N ceramic coatings on titanium”, Applied Surface Science, v.346, pp.428-437, Aug 2015.

[45] DAS, M., BALLA, V.K., KUMAR, T.S.S., et al., "Tribological, electrochemical and in vitro biocompatibility properties of SiC reinforced composite coatings", Materials and Design, v.95, n.5, pp.510 517, Apr 2016.

[46] GUALTIERI, T., BANDYOPADHYAY, A., “Additive manufacturing of compositionally gradient metal-ceramic structures: Stainless steel to vanadium carbide”, Materials and Design, v.139, n.5, pp.419428, Feb 2018.

[47] LIU, W., DUPONT, J., "Fabrication of Carbide Particle Reinforced Titanium Aluminide Matrix Composites by Laser Engineered Net Shaping”, Metallurgical and materials transactions A, v.35, n.13, pp.1133-1140, Mar 2004. 
[48] ZHANG, Y., BANDYOPADHYAY, A., "Direct fabrication of compositionally graded Ti-A12O3 multimaterial structures using Laser Engineered Net Shaping”, Additive Manufacturing, v.21, pp.104-111, May 2018.

[49] ZHENG, B., SMUGERESKY, J.E., ZHOU, Y., et al., "Microstructure and properties of laser-deposited Ti6Al4V metal matrix composites using Ni-Coated powder", Metallurgical and Materials Transactions A, v.39, n.5, pp.1196-1205, May 2008.

[50] OCHONOGOR, O.F., MEACOCK, C., PITYANA, S.L., et al., "Microstructure characterization of laser- deposited titanium carbide and zirconium- based titanium metal matrix composites", The Journal of the Southern African Institute of Mining and Metallurgy, v.112, n.10, pp.905-910, Dec 2012.

[51] ŁAZIŃSKA, M., DUREJKO, T., POLKOWSKI, W., "The effect of nanometric $\alpha-\mathrm{Al} 2 \mathrm{O} 3$ addition on structure and mechanical properties of feal alloys fabricated by lens technique", Archives of Metallurgy and Materials, v.62, n.3, pp.1703-1712, 2017.

\section{ORCID}

Italo Leite de Camargo João Fiore Parreira Lovo Rogério Erbereli Reginaldo Teixeira Coelho Iris Bento da Silva Carlos Alberto Fortulan https://orcid.org/0000-0001-8329-6799

https://orcid.org/0000-0002-2371-4650

https://orcid.org/0000-0003-0753-8172

https://orcid.org/0000-0001-8154-5421

https://orcid.org/0000-0001-8269-092X

https://orcid.org/0000-0002-2259-9910 